\title{
THE EFFECT OF MINERAL ADSORBENT IN CALF DIET COLOSTRUM ON THE LEVELS OF SERUM IMMUNOGLOBULIN G, PROTEIN AND GLUCOSE
}

FRATRIĆ NATALIJA, STOJIĆ V, RAJČIĆ S and RADOJIČIĆ BILJANA

Faculty of Veterinary Medicine, Belgrade

(Received 7. January 2007)

The aim of the study was to investigate the influence of added natural mineral adsorbent zeolite (clinoptylolite) on the degree of absorption of immunoglobulin $G$ and on glucose and protein concentration in the blood of calves during the neonatal period.

Sixty calves were randomly divided in to four groups (15 calves per group). The quality and timing of colostrum feeding was as follows: group I was fed only with $1.5 \mathrm{~L}$ of colostrum at $2 \mathrm{nd}, 12 \mathrm{th}, 24$ th and 36 th hour after birth; group II was fed with $1.5 \mathrm{~L}$ of colostrum with the mineral adsorbent added at a 5\% concentration in the same time intervals; group III was fed with $1.5 \mathrm{~L}$ of colostrum together with the mineral adsorbent added at a 5\% concentration, but at 2nd and 12 hour after birth it was fed with the first colostrum, and 24 and 36 hours after birth it was fed with the second colostrum. Group IV of calves was fed the same way as the third one only without the addition of the mineral adsorbent.

Mean serum concentration of $\lg G$ was $15.14 \pm 7.43 ; 22.22 \pm 8.15$; $23.65 \pm 9.93 ; 20.81 \pm 4.19 \mathrm{~g} / \mathrm{L}$ in groups I to IV respectively at $6 \mathrm{~h}$ of age. IgG concentration in the sera of all groups were 29.10 \pm 15.25 ; $45.46 \pm 13.45 ; 50.72 \pm 21.57 ; 41.60 \pm 15.42 \mathrm{~g} / \mathrm{L}$ respectively at $16 \mathrm{~h}$ after birth. At 30 hours of age, concentration of IgG was $33.29 \pm 14.70$; $47.05 \pm 12.38$; $55.00 \pm 19.71 ; 51.59 \pm 13.82 \mathrm{~g} / \mathrm{L}$ in groups I to $\mathrm{IV}$ respectively. IgG concentration in the sera of all groups were $29.82 \pm 12.69 ; \quad 44.10 \pm 13.50 ; \quad 51.88 \pm 20.14 ; \quad 47.68 \pm 13.18 \mathrm{~g} / \mathrm{L}$ respectively at 40 hours after birth.

For the calves which were fed with the full colostrum without and with the addidition of the mineral adsorbent (Group I and II) the statistical significance of the difference in the concentration of IgG was determined during all the tested intervals. Concentration of IgG in the sera of group II calves (fed colostrum with zeolite added) was approximately $30 \%$ higher than in the group I.

The statistical significance of the difference in levels of IgG between group I and groups III an IV was determined during all tested intervals, also. Concentration of IgG in the sera of group III calves was $40 \%$ higher than in group $I$. 
Results suggest that calves should receive feedings of high quality colostrum with added mineral adsorbent in order to maximize colostral IgG absorption.

Determining the proteinemia in the neonatal period of calves is a reliable indicator of the impact of the mineral adsorbent on the degree of absorption of colostral lgG.

The concentration of glucose for all the tested groups increased significantly with the increase of the quantity of ingested colostrum, with no evident influence of the added mineral adsorbent.

Key words: colostrum, newborn calves, imunoglobulins, IgG, clinoptilolite

\section{INTRODUCTION}

Bovine colostrum contains higher amounts of proteins and peptides, fats, fat-soluble vitamins, and various enzymes, hormones, growth factors, cytokines, minerals and nucleotides than mature milk, and except lactose, the levels of those compounds rapidly decrease during the first 3 days of lactation to those typical for mature milk (Campana and Baumrucker, 1995; Blum and Hammon, 2000a, $2000 b)$. Colostrum intake in neonatal calves is essential for passive immunity and influences matabolism, endocrine system and nutritional state (Guilloteau et al., 1997). Ingested immunoglobulins, some proteins and enzymes are absorbed in particular during the first hours after birth (Baumrucker et al., 1994b; Hadorn and Blum, 1997; Hammon and Blum, 1998).

Inadequate or improper colostrum feeding and management causes a significant portion of calf morbidity and mortality on dairy farms. The importance of ingestion of adequate colostrum of suitable quality is critical in the first $24 \mathrm{~h}$ of life (Matte et al., 1982; Hammon and Blum, 1998; Blum and Hammon, 2000). In animals with epitheliochorial type of placenta such as pigs, sheep, cattle, transplacental passage of immunoglobulin molecules is totally prevented. Calves are born with almost no serum Ig under physiological conditions (hypogammaglobulinemic state) and aquire passive immunity by absorbing immunoglobulins from the colostrum (Stott et al., 1979; Stott and Fellah, 1983; Weaver et al., 2000). Colostrum contains high levels of immunoglobulins. There are 3 types of lg (IgG, $\lg \mathrm{M}, \lg \mathrm{A})$ in the colostrum, which typically account for about $85 \%$ to $90 \%, 5 \%$, and $7 \%$, respectively, of total Ig in colostrum (Roy, 1980). These Ig provide the calf with passive immunity (immunity provided by the cow) until the calf"s own active immunity developes (Korhonen et al., 2000).

Immunoglobulin intake depends on colostrum intake and its Ig concentration. Immunoglobulin ingested by the calf is taken up by epithelial cells of the small intestine and passes into the lymph spaces and then into the blood circulation. This transport mechanism starts to decline approximately 12 to 24 hours after birth (Vukotić 1976, 1972; Kiryama et al., 1989; Arthington et al., 2000; Korhonen et al., 2000; Rauprich et al., 2000; Franklin et al., 2003). Although the level of Ig that provides adequate protection will vary with exposure to infectious 
organisms, stress, environment, and temperature, a menagement target of $10 \mathrm{mg} / \mathrm{mL}$ has been suggested as a minimum level of IgG in the serum of calves by approximately $24 \mathrm{~h}$ of age to prevent failure of passive transfer (Bovine Alliance on Management and Nutrition, 1995).

Numerous authors consider that 38 hours after birth the absorption of immunoglobulins from colostrum has ceased. It has been proposed that gut closure is associated with postnatal replacement of fetally produced intestinal enterocytes with cells incapable of internalizing macromolecules (Smith, 1988; Rou-Xu, 1996). Postanatal enterocite differention may also contribute to the gut closure process.

Since colostral Ig are the key factor of humoral immunity in newborn calves and during the first few weeks of their life, many authors have studied conditions under which the degree of absorption of colostral immunoglobulins (lg) may be increased, such as: the way in which colostrum is fed to calves, the time at which colostrum was first ingested, the effect of the concentration of immunoglobulins in the colostrum, and the efficiency of absorption of Ig by the calf (Kruse et al., 1970; Stott et al., 1979; Stott et al., 1981; Besser et al., 1985; Pritchett et al., 1991; Morin et al., 1997; Hopkins et al., 1997; Davenport et al., 2000).

The effects of a mineral adsorbent, based on clinoptilolite, have been widely applied in domestic animals in the last ten years (Stankov et al., 1992; TomaševićČanović et al., 1994; Petrović et al., 1995; Rajić et al., 1995; Stojić et al.,1995; 1998).

Stojić et al. (1995, 1998), examined the effects of a clinoptilolite based adsorber added to colostrum on the degree of absorption of colostral immunoglobulin $\mathrm{G}$ in newborn animals. They showed that a clinoptilolite based mineral adsorbent in the colostrum leads to a significantly higher absorption of colostrum IgG in newborn calves and piglets.

The aim of our investigation was to determine the effect of prolonged clinoptilolite enriched first colostrum feeding on absorption and serum concentration of immunoglobulin $\mathrm{G}$ in newborn calves, during the first 48 hours of life.

\section{MATERIAL AND METHODS}

Animals.

The experiment was carried out on 60 calves, divided in four groups (15 calves per group). Experimental group I. Each of the 15 calves received $1.5 \mathrm{~L}$ of colostrum at 2, 12, 24 and 36 hours after birth; Experimental group II. Each of the 15 calves received $1.5 \mathrm{~L}$ of colostrum with the mineral adsorbent in a $5 \%$ concentration in the same time intervals; Experimental group III. Each of the 15 calves received $1.5 \mathrm{~L}$ of colostrum together with the mineral adsorbent in a $5 \%$ concentration, but 2 and 12 hours after birth it was fed with the first colostrum and at 24 and 36 hours it was fed with the second colostrum; Experimental group IV. Each of the 15 calves was fed in the same way as the third group but without the addition of the mineral adsorbent. 


\section{Blood sampling.}

Blood samples were taken from the jugular vein at $6,16,30$, and 40 hours after birth. After spontaneous coagulation at room temperature, the serum was separated and frozen at $-20^{\circ} \mathrm{C}$ for subsequent analysis.

Mineral adsorber. The examined mineral adsorber was obtained by technological preparation of the zeolitic tuff from the Zlatokop (South Serbia) deposit. Mineral composition: the basic component is clinoptilolite with the presence of quartz and plagioclase. Clinoptilolite (Minazel -S, ITNMS, Beograd, Serbia) suspension was prepared according to the producer's instructions.

\section{Methods}

Immunodiffusion. Immunoglobulin G concentrations in the blood sera of calves and colostral sera were determined using double immunodiffusion on commercial RID plates (INEP-Zemun, SRB).

Total protein concentration was determined by the colorimetric method

Serum enzyme activities (AST, ALT) were measured by commercially available kits and a clinical biochemical analyzer.

Glucose was measured using kits from Hoffman-LaRoche (Basle, Switzerland) and an automatic analyzer (Secomam CE, BP 106). All assays were performed in duplicate and all samples were analyzed within the same run of an assay.

Statistical analysis. The results are expressed as mean (M), standard deviation (SD), standard error (SE) and variation coefficient (CV\%). The significance of differences between groups was calculated using Students t-test.

\section{RESULTS}

Concentrations of serum immunoglobulin $G$ in calves of experimental groups IIV at 6, 16, 30 and 48 hours after birth are shown in Table 1, 2.

Table 1. Concentrations of serum immunoglobulin $\mathrm{G}$ in calves from experimental group I and group II after colostrum intake

\begin{tabular}{|c|c|c|c|c|c|c|c|c|}
\hline \multirow{2}{*}{} & \multicolumn{4}{|c|}{ Experimental group I } & \multicolumn{4}{c|}{ Experimental group II (zeolite) } \\
\cline { 2 - 9 } & \multicolumn{3}{|c|}{ IgG conc (g/L) } & \multicolumn{4}{c|}{ IgG conc (g/L) } \\
\cline { 2 - 9 } & $6 \mathrm{~h}$ & $16 \mathrm{~h}$ & \multicolumn{1}{|c|}{$30 \mathrm{~h}$} & \multicolumn{1}{c|}{$40 \mathrm{~h}$} & $6 \mathrm{~h}$ & $16 \mathrm{~h}$ & $30 \mathrm{~h}$ & \multicolumn{1}{|c|}{$40 \mathrm{~h}$} \\
\hline \hline Mean & 15.14 & 29.10 & 33.29 & 29.82 & 22.22 & 45.46 & 47.05 & 44.10 \\
\hline SD & 7.43 & 15.25 & 14.70 & 12.69 & 8.15 & 13.45 & 12.38 & 13.50 \\
\hline SE & 1.92 & 3.93 & 3.79 & 3.27 & 2.10 & 3.47 & 3.19 & 3.48 \\
\hline CV\% & 49.07 & 52.40 & 44.15 & 43.45 & 36.67 & 29.58 & 26.31 & 30.61 \\
\hline
\end{tabular}


Acta Veterinaria (Beograd), Vol. 57, No. 2-3, 169-180, 2007.

Fratrić Natalija et al.: The effect of mineral adsorbent in calf diet colostrum

on the levels of serum immunoglobulin $\mathrm{G}$, protein and glucose

Table 2. Concentrations of serum immunoglobulin $\mathrm{G}$ in calves from experimental group III and group IV after colostrum intake

\begin{tabular}{|c|r|r|r|r|r|r|r|r|}
\hline \multirow{2}{*}{} & \multicolumn{4}{|c|}{ Experimental group III (zeolite) } & \multicolumn{4}{c|}{ Experimental group IV } \\
\cline { 2 - 9 } & \multicolumn{4}{|c|}{ IgG conc (g/L) } & \multicolumn{4}{c|}{ IgG conc (g/L) } \\
\cline { 2 - 9 } & \multicolumn{1}{|c|}{$6 \mathrm{~h}$} & $16 \mathrm{~h}$ & \multicolumn{1}{|c|}{$30 \mathrm{~h}$} & \multicolumn{1}{c|}{$40 \mathrm{~h}$} & $6 \mathrm{~h}$ & $16 \mathrm{~h}$ & \multicolumn{1}{|c|}{$30 \mathrm{~h}$} & $40 \mathrm{~h}$ \\
\hline \hline Mean & 23.65 & 50.72 & 55.00 & 51.88 & 20.81 & 41.60 & 51.59 & 47.68 \\
\hline SD & 9.93 & 21.57 & 19.71 & 20.14 & 4.19 & 15.42 & 13.82 & 13.18 \\
\hline SE & 2.65 & 5.57 & 5.09 & 5.20 & 1.08 & 3.98 & 3.56 & 3.40 \\
\hline CV\% & 41.98 & 42.52 & 36.83 & 38.82 & 20.13 & 37.06 & 26.78 & 27.64 \\
\hline
\end{tabular}

Results indicated that the concentration of IgG in the serum increased significantly after colostrum intake. Mean immunoglobulin $\mathrm{G}$ concentrations in the serum of calves from experimental group I and II 6 hours after birth were $15.14 \pm 7.43 \mathrm{~g} / \mathrm{L}$ and $22.22 \pm 8.15 \mathrm{~g} / \mathrm{L}$, respectively.

At the same time, IgG concentrations in the serum of the experimental groups III and IV were $23.65 \pm 9.93 \mathrm{~g} / \mathrm{L}$ and $20.81 \pm 4.19 \mathrm{~g} / \mathrm{L}$, respectively.

The mean immunoglobulin $G$ concentration in the serum of calves from experimental groups I and II 16 hours after birth were $29.10 \pm 15.25 \mathrm{~g} / \mathrm{L}$ and $45.46 \pm 13.45 \mathrm{~g} / \mathrm{L}$. At the same time, in the serum of the experimental groups III and IV were $50.72 \pm 21.57 \mathrm{~g} / \mathrm{L}$ and $41.60 \pm 15.42 \mathrm{~g} / \mathrm{L}$, respectively.

The mean immunoglobulin $\mathrm{G}$ concentrations in the serum of calves from experimental groups I and II 30 hours after birth were $33.29 \pm 14.70 \mathrm{~g} / \mathrm{L}$ and $47.05 \pm 12.38 \mathrm{~g} / \mathrm{L}$ respectively. Concentrations of $\mathrm{IgG}$ in the serum of calves from

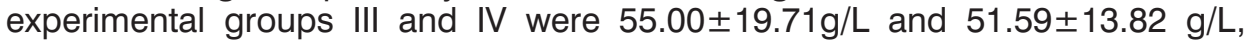
respectively.

The mean immunoglobulin $G$ concentrations in the calf sera from experimental groups I and II 40 hours after birth were $29.82 \pm 12.69 \mathrm{~g} / \mathrm{L}$ and $44.10 \pm 13.50 \mathrm{~g} / \mathrm{L}$ respectively. Concentrations of $\mathrm{IgG}$ in the serum of calves from experimental groups III and IV were $51.88 \pm 20.14 \mathrm{~g} / \mathrm{L}$ and $47.68 \pm 13.18 \mathrm{~g} / \mathrm{L}$, respectively.

Significantly higher concentrations of serum IgG were found in calves from experimental group II compared to group I, $6 \mathrm{~h}(\mathrm{p}<0.05), 16 \mathrm{~h}(\mathrm{p}<0.01)$, 30h $(p<0.01)$ and 40h $(p<0.01)$ after birth.

The difference in the mean concentrations of IgG between experimental groups I and IV was higher 6 hours after birth $(p<0.05)$, 16h $(p<0.05)$, 30h $(p<0.01)$, and 40h $(p<0.001)$ after birth. Significantly higher concentrations of serum IgG were found in calves from experimental group IV compared with experimental group I.

Our results showed that the mean concentration of $\lg G$ between experimental group II and group III and IV was not statistically significant. Also the difference was not statistically significant for the levels of IgG between groups III and IV. 
Concentration of IgG in sera of calves group II where fed colostrum with added zeolite was approximately $30 \%$ higher than in the group I (which was fed with colostrum without zeolite). Concentration of IgG in sera of calves in group III was $40 \%$ higher than in group I. Although, no significant statistical difference was found between the groups which were fed with the mineral adsorbent (II and III group), but the concentration of IgG in group III was $10-20 \%$ higher than in group II.

Results suggest that calves should receive feedings of high quality colostrum with mineral adsorbent added in order to maximize the colostral IgG absorption.

Concentration of IgG in sera of group II calves (fed colostrum with added zeolite) was higher at $6 \mathrm{~h}$ and $16 \mathrm{~h}$ compared to the concentration of IgG in group IV in the same period, but at $30 \mathrm{~h}$ and $40 \mathrm{~h}$ the concentration of IgG in group IV was higher than in group II.

These results show the impotance of clinoptilolite on IgG absorption, especially in the first 24 hours of postnatal life. Our results suggest that feeding high quality colostrum with added mineral adsorbent in the first two days after birth has an influence on high IgG concentrations in blood sera.

The data from this investigation show that clinoptilolite based mineral adsorbent addeded to colostrum leads to a significantly higher degree of absorption of colostral IgG in newborn calves, which has medical and economic effects.

The protein concentration is increased significantly after intake colostrum (Table 3,4$)$. Determining proteinemia in the neonatal period of calves is a reliable indicator of the impact of the mineral adsorbent on the degree of the absorption of colostral lgG.

The glucose concentration for all the tested groups increased significantly with the increase of the quantity of ingested colostrum, without larger influence of the mineral adsorbent (Table 5, 6).

Table 3. Concentrations of total protein $(\mathrm{g} / \mathrm{L})$ in serum of calves from experimental group I and group II after colostrum intake

\begin{tabular}{|c|c|c|c|c|c|c|c|c|}
\hline & \multicolumn{4}{|c|}{ Experimental group I } & \multicolumn{4}{c|}{ Experimental group II (zeolite) } \\
\cline { 2 - 9 } & \multicolumn{3}{|c|}{ protein conc (g/L) } & \multicolumn{4}{c|}{ protein conc (g/L) } \\
\cline { 2 - 9 } & $6 \mathrm{~h}$ & $16 \mathrm{~h}$ & $30 \mathrm{~h}$ & $40 \mathrm{~h}$ & $6 \mathrm{~h}$ & $16 \mathrm{~h}$ & $30 \mathrm{~h}$ & $40 \mathrm{~h}$ \\
\hline \hline Mean & 47.89 & 59.59 & 64.44 & 61.56 & 57.0 & 83.7 & 87.3 & 81.2 \\
\hline SD & 13.89 & 14.60 & 19.84 & 15.77 & 12.50 & 15.59 & 14.18 & 17.52 \\
\hline SE & 3.58 & 3.77 & 5.12 & 4.07 & 3.23 & 4.02 & 3.66 & 4.52 \\
\hline CV\% & 29.00 & 24.50 & 30.78 & 25.61 & 21.92 & 18.62 & 16.24 & 21.57 \\
\hline
\end{tabular}


Acta Veterinaria (Beograd), Vol. 57, No. 2-3, 169-180, 2007.

Fratrić Natalija et al.: The effect of mineral adsorbent in calf diet colostrum

on the levels of serum immunoglobulin $\mathrm{G}$, protein and glucose

Table 4. Concentrations of total protein $(\mathrm{g} / \mathrm{L})$ in serum of calves from experimental group III and group IV after colostrum intake

\begin{tabular}{|c|r|r|r|r|r|r|r|r|}
\hline & \multicolumn{4}{|c|}{ Experimental group III } & \multicolumn{4}{c|}{ Experimental group IV (zeolite) } \\
\cline { 2 - 9 } & \multicolumn{3}{|c|}{ protein conc (g/L) } & \multicolumn{4}{c|}{ protein conc (g/L) } \\
\cline { 2 - 9 } & $6 \mathrm{~h}$ & $16 \mathrm{~h}$ & \multicolumn{1}{|c|}{$30 \mathrm{~h}$} & \multicolumn{1}{|c|}{$40 \mathrm{~h}$} & $6 \mathrm{~h}$ & $16 \mathrm{~h}$ & $30 \mathrm{~h}$ & $40 \mathrm{~h}$ \\
\hline \hline Mean & 55.80 & 84.22 & 86.32 & 83.64 & 58.95 & 76.74 & 85.2 & 96.8 \\
\hline SD & 12.99 & 24.39 & 23.11 & 27.88 & 7.31 & 17.80 & 16.57 & 19.54 \\
\hline SE & 3.35 & 6.29 & 5.96 & 7.19 & 1.88 & 4.59 & 4.27 & 5.04 \\
\hline CV\% & 23.27 & 28.95 & 26.77 & 33.33 & 12.40 & 23.19 & 19.44 & 20.18 \\
\hline
\end{tabular}

Table 5. Concentrations of glucose $(\mathrm{mmol} / \mathrm{L})$ in serum of calves from experimental group I and group I I after colostrum intake

\begin{tabular}{|c|c|c|c|c|c|c|c|c|}
\hline & \multicolumn{4}{|c|}{ Experimental group I } & \multicolumn{4}{c|}{ Experimental group II (zeolite) } \\
\cline { 2 - 9 } & \multicolumn{3}{|c|}{ glucose (mmol/L) } & \multicolumn{4}{c|}{ glucose (mmol/L) } \\
\cline { 2 - 9 } & $6 \mathrm{~h}$ & $16 \mathrm{~h}$ & $30 \mathrm{~h}$ & $40 \mathrm{~h}$ & $6 \mathrm{~h}$ & $16 \mathrm{~h}$ & $30 \mathrm{~h}$ & $40 \mathrm{~h}$ \\
\hline \hline Mean & 3.02 & 4.84 & 5.34 & 5.68 & 2.70 & 5.24 & 5.61 & 6.21 \\
\hline SD & 0.50 & 1.09 & 0.96 & 0.71 & 0.76 & 1.69 & 1.20 & 0.81 \\
\hline SE & 0.13 & 0.30 & 0.24 & 0.19 & 0.19 & 0.43 & 0.31 & 0.21 \\
\hline CV\% & 16.5 & 22.5 & 17.97 & 12.5 & 28.14 & 32.25 & 21.39 & 13.04 \\
\hline
\end{tabular}

Table 6. Concentrations of glucose $(\mathrm{mmol} / \mathrm{L})$ in serum of calves from experimental group III and group IV after colostrum intake

\begin{tabular}{|c|c|c|c|c|c|c|c|c|}
\hline & \multicolumn{4}{|c|}{ Experimental group III } & \multicolumn{4}{c|}{ Experimental group IV (zeolite) } \\
\cline { 2 - 9 } & \multicolumn{4}{|c|}{ glucose (mmol/L) } & \multicolumn{4}{c|}{ glucose (mmol/L) } \\
\cline { 2 - 9 } & $6 \mathrm{~h}$ & $16 \mathrm{~h}$ & $30 \mathrm{~h}$ & $40 \mathrm{~h}$ & $6 \mathrm{~h}$ & $16 \mathrm{~h}$ & $30 \mathrm{~h}$ & $40 \mathrm{~h}$ \\
\hline \hline Mean & 2.93 & 4.66 & 5.52 & 5.70 & 3.92 & 5.96 & 6.41 & 7.01 \\
\hline SD & 0.75 & 1.05 & 1.06 & 1.00 & 0.80 & 1.27 & 1.35 & 1.23 \\
\hline SE & 0.19 & 0.27 & 0.27 & 0.25 & 0.20 & 0.32 & 0.34 & 0.31 \\
\hline CV\% & 25.59 & 22.53 & 19.20 & 18.18 & 20,40 & 21.3 & 21.06 & 17.54 \\
\hline
\end{tabular}

\section{DISCUSSION}

Colostrum intake in neonatal calves is essential for passive immunity. It is critically important to feed colostrum immediately after birth. The intestine of a newborn is capable of absorbing large intact protein molecules (such as 
immunoglobulins-lg) within the first 24 hours of life, resulting in an increase in circulating IgG concentration in the calf's blood (Stott et al., 1979; Morin et al., 1997). Our results show that concentrations of IgG were much higher after colostrum intake, which is in accordance with many authors (Rajala and Castren, 1995; Gu-Hyun Suh et al., 2003; Jaster, 2005).

Since colostral Ig are the key factor of humoral immunity in newborn calves and during the first few weeks of their life, authors have studied conditions under which the degree of absorption of colostral immunoglobulins (Ig) may be increased (Denise, 1989; Hopkins et al., 1997; Davenport et al., 2000). Authors investigated factors such as the way in which colostrum is fed to calves, the time at which colostrum was first ingested, the effect of the concentration of immunoglobulins in the colostrum, the extent of concentration of immunoglobulins in the colostrum and the efficiency of absorption of Ig by the calf (Matte et al., 1982; Besser et al., 1985; Morin et al., 1997).

The effects of a mineral adsorbent, based on clinoptilolite, have been widely applied in domestic animals in the last ten years (Stankov et al., 1992; TomaševićČanović et al., 1994; Petrović et al., 1995; Kovačević, 2000, Janković, 2004; Bojković, 2005; Fratrić et al., 2005; Stojić et al., 2005). Stojić et al. (1995; 1998), showed that a clinoptilolite based mineral adsorbent in the colostrum $5 \mathrm{~g} / \mathrm{L}$ suspension leads to a significantly higher absorption of colostrum IgG in newborn calves and piglets.

Our results also clearly indicate that a clinoptilolite based mineral adsorber in the colostrum led to a significant increase of IgG concentrations in the blood of newborn calves. These data additionally support the above mentioned opinion about the possible mode of clinoptilolite action to increase the absorption of colostral IgG. Our data for IgG concentrations are in accordance with previous studies by a number of authors (Kovačević, 2000; Janković, 2004; Fratrić et al., 2005; Stojić et al., 2005).

The question on the mechanism of influence of clinoptilolite on increased IgG adsorption is still open. However, since it has been shown that this mineral adsorbent efficiently binds aflatoxins $B 1$ and $G 1$, we can speculate that in conditions of high protein intake and absence of digestive enzymes, it may bind some degradation products of colostral proteins in the gut, thus preventing their negative effects on mucosal epithelial cells designated for immunoglobulin absorption. We can assume that clinoptilolite based mineral adsorbent could be of influence on a longer life time of mucosal epithelial cells which have more Fc receptors for IgG compared with the next generation of enterocytes. The resorption capacity of enterocytes for IgG exceed than the overall IgG concentration in $1.5 \mathrm{~L}$ of colostrum, which shows that calves can ingest more than $1.5 \mathrm{~L}$ of colostrum.

Changes in neonatal calf proteinemia are a consequence of abundant absorption of colostral proteins, specially immunoglobulins in the first hours of life. Our data for protein concentrations were similar to those previosly reported by many other authors (Vukotic, 1972; Mao et al., 1994; Adams et al., 1992; Kuhne et al., 2000). The significantly higher serum protein concentration in the groups which consumed colostrum with added zeolite indicates that proteinemia in the 
Acta Veterinaria (Beograd), Vol. 57, No. 2-3, 169-180, 2007.

neonatal period in calves is a reliable indicator of the impact of the mineral adsorbent on the degree of the absorption of colostral IgG. The significantly higher serum protein concentration in the groups which consumed colostrum with zeolite indicates that the quality of colostrum consumed during the first 40 hours of postnatal life had a prolonged effect on the concentration of serum proteins, probably as a consequence of the long half-life of circulating immunoglobulins.

At 40 hours of age, calves fed colostrum with higher a concentration of total ingested IgG (group IV) had the highest serum protein concentrations which indicate that the quality of colostrum consumed during the first 40 hours of postnatal life had a prolonged effect on the concentration of serum proteins. This is an agreement with reports by Hammon and Blum (1998) and Jaster (2005).

The concentrations of glucose for all the tested groups increase significantly with the increase of quantity of ingested colostrum, without significant influence of the mineral adsorbent. Our data on glucose concentrations is in agreement with published data of other investigators (Grutter et al., 1991; Kurz and Willett, 1991; Kuhne et al., 2000).

\section{ACKNOWLEDGMENT}

This work was supported by the Ministry of Science and Technology of Serbia project No.143022.

Address for correspondence:

Natalija Fratrić PhD

Faculty of Veterinary Medicine

Department of Physiology and Biochemistry

Bul Joslobodenja 18, 11000 Beograd

Serbia

e-mail:nataly@vet.bg.ac.yu

\section{REFERENCES}

1. Adams R, Garry FB, Aldridge BM, Holland MD, Oddle KG, 1992, Hematologic values in newborn beef caves, Am J Vet Res, 53, 944-50.

2. Arthington JD, Cattell MB, Quigley JD, 2000, Effect of dietary IgG source (colostrum, serum, or milkderived supplement) on the efficiency of Ig absorption in newborn Holstein calves, J Dairy Sci, 83, $1463-7$.

3. Baumrucker CR, Green MH, Blum JW, 1994b, Effects of dietary rhIGF-I in neonatal calves on the appearance of glucose, insulin, d-xylose, globulins and gamma-glutamyl transferase in blood, Domest Anim Endocrinol, 11, 393-403.

4. Besser TE, Garmedia AE, McGuire TC, Gay CC, 1985, Effect of colostral IgG 1 and IgM concentrations on immunoglobulin absorption in calves, J Dairy Sci, 68, 2033-7.

5. Blattler U, Hammon HM, Morel C, Philipona C, Rauprich A, Rome V, Huërou-Luron LI, Guilloteau P, Blum JW, 2001, Feeding colostrum, its composition and feeding duration variably modify proliferation and morphology of the intestine and digestive enzyme activities of neonatal calves, Journal of Nutrition, 131, 1256-63.

6. Blum JW, Hammon HM, 2000a, Kolostrum-mehr als nur ein Immunoglobulinlieferant, Schweiz Arch tierheilkde, 5, 221-8.

7. Blum JW, Hammon HM, 2000b, Colostrum effects on the gastrointestinal tract, and on nutritional, endocrine and metabolic parameters in neonatal calves, Lifest Prod Sci, 66, 1151-9. 
8. Bojković Slavica, 2005, Ispitivnje uticaja mineralnog adsorbenta zeolita na bazi klinoptilolita na stepen resorpcije kolostralnih imunoglobulina G, glikemiju i prirast prasadi u neonatalnom periodu. Magistarski rad. Fakultet vet. med. Beograd.

9. Bovine Alliance on Menagement and Nutrition, 1995, A quide to colostrum and colostrum menagement for dairy calves, American Feed Industry Association, Arlington, VA.

10. Campana WM, and Baumrucker $C R, 1995$, Hormones and growth factors in bovine milk, Jensen RG, eds, Handbook of Milk Composition, Academic press San Diego, Ca, 476-94.

11. Denise SK, 1989, Effects of passive immunity on subsequent production in dairy heifers, J Dairy Sci, 72, 552-4.

12. Devenport DF, Quigley JD, Martin JE, Holt JA, Arthington JD, 2000, Addition of casein or whey protein to colostrum or a colostrum supplement product on absorption of IgG in neonatal calves, J Dairy Sci, 83, 2813-9.

13. Franklin ST, Amaral-Phillips DM, Jackson JA, Campbell AA, 2003, Health and performance of Holstein calves that suckled or were hand-fed colostrum and were fed one of three physical forms of starter, J Dairy Sci, 86, 2145-53.

14. Fratrić $N$, Stojić V, Janković $D$, Šamanc $H$, Gvozdić $D, 2005$, The effect of a clinoptilolite based mineral adsorber on concentrations of immunoglobulin $\mathrm{G}$ in the serum of newborn calves fed different amounts of colostrum, Acta Veterinaria, 55, 1, 11-21.

15. Grutter R, Blum JW, 1991, Insulin and glucose in neonatal calves after peroral insulin and intravenous glucose administration, Reprod Nutr Dev, 31,389-97.

16. Guilloteau P, Le huërou-Luron I, Chayvialle JA, Toullec R, Zabielski R, Blum JW, 1997, Gut regulatory peptides in young cattle and sheep, J Vet Med, A44, 1-23.

17. Guk-Hyun Suh, Tai-Young Hur, Dong-Soo Son, Chang-yong Choe, Young -Hun Jung, Byeong-suk Ahn, Chai-Yong Lee and Chung-Gil Lee, 2003, Differences in the serum immunoglobulin concentrations between dairy and beef calves from birth to 14 days of age, $J$ Vet Sci, 4, 257-60.

18. Hadorn U, and Blum JW, 1997, Effect of feeding colostrum, glucose or water on the first day of life on plasma immunoglobulin $G$ concentration and gamma-glutamyltransferase activities in calves, $J$ Vet Med, A44, 531-7.

19. Hammon H and Blum JW, 1998, Metabolic and endocrine traits of neonatal calves are influenced by feeding colostrum for different duration or only milk replacer, J Nutr, 128, 624-32.

20. Hiroko Kiriyama, Etsumori Harada, Bunei Syuto, 1989, Analysis of Colostrum in Calf Serum by Enzyme-Linked Immunosorbent Assay, J Dairy Sci, 72, 398-406.

21. Hopkins BA, Quigley JD, 1997, Effect of method of colostrum feeding and colostral supplementation on serum IgG concentrations in neonatal calves, J Dairy Sci, 80, 979-83.

22. Janković $T D, 2004$, Uticaj prirodnog zeolita na bazi klinoptilolita na kvantitativne i kvalitativne promene proteina krvnog seruma teladi u neonatalnom periodu. Magistarska rad. Fakultet vet. med. Beograd.

23. Jaster $E H, 2005$, Evaluation of quality, quantity, and timing of colostrum feeding on immunoglobulin G1 absorption in Jersey calves, J Dairy Sci, 88, 296-302.

24. Korhonen H, Marnila P, Gill HS, 2000, Milk immunoglobulins and complement factors, Br J Nutr, 84, 75-80.

25. Kovačević VB, 2000, Ispitivanje uticaja prirodnih zeolita na neke biohemijske i hematološke parametre krvi kod teladi, Magistarski rad, Fakultet veterinarske medicine, Univerzitet $u$ Beogradu.

26. Kuhne S, Hammon HM, Bruckmaier RM, Morel C, Zbinden Y, Blum JW, 2000, Growth performance, metabolic and endocrine traits, and absorptive capacity in neonatal calves fed either colostrum or milk replacer at two levels, J Anim Sci, 78, 609-20.

27. Kurz MM, Willett LB, 1991, Carbohydrate, enzyme, and hematology dynamics in newborn calves. $J$ Dairy Sci, 74, 2109-18.

28. Mao XZ, Li SZ, Zhu ZK, Qin WL, 1994, The development changes and correlations of some blood hormone levels and immune index during the postnatal period in neonatal calves, $J$ Vet Med Ser $A, 41,405-12$. 
Acta Veterinaria (Beograd), Vol. 57, No. 2-3, 169-180, 2007.

29. Matte JJ, Girard CL, Seoane JR, Brisson GJ, 1982, Absortion of colostral immunoglobulin G in the newborn dairy calf, J Dairy Sci, 65, 1765-70.

30. Morin DE, McCoy GC, HurleyWL, 1997, Effect of quality, quantity, and timing of colostrum feeding and addition of a dried colostrum supplement on immunoglobulin G1 absorption in Holstein bull calves, J, Dairy Sci, 80, 747-53.

31. Petrović $M$, Kastolan-Macan M, Kralj M, 1995, Quantitative chromatographic analysis of aminoacids on natural zeolite thin layers, Sofia Zeolite Meeting, Intern, Symp, on Natural Zeolite, Sofia, 77.

32. Pritchett LC, Gay CC, Besser TE, Hancock DD, 1991, Menagement and production factors influencing immunoglobulin G1 concentration in colostrum from Holstein cows, J, Dairy Sci, 74, 2336-9.

33. Rajala P, Castren H, 1995, Serum immunoglobulin concentrations and health of dairy calves in two menagement systems from birth to 12 weeks of age, J Dairy Sci, 78, 2737-44.

34. Rajić I, Trajković D, Tomašević-Čanović M, Dunić M, Vukićević O, Bočarov A, 1995, Effect of Minazel added to zearalenone and ochratoxin contaminated diets of pregnant sows on the bearing results, Veterinarski glasnik, 48, 881-8.

35. Rauprich ABE, Hammon HM, Blum JW, 2000, Influence of feeding different amounts of first colostrum on metabolic, endocrine and health status and on growth performance in neonatal calves, J Anim Sci, 78, 896 - 908.

36. Rou-Jun Xu, 1996, Development of the newborn Gl tract and its relation to colostrum/milk intake, Reprod Fertil Dev, 8, 35-48.

37. Roy JHB, 1980, Factor affecting susceptibility of calves to disese, J Dairy Sci, 63, 650-64.

38. Smith MW, 1988, Postnatal development of transport function in the pig intestine, Comparative Biochemistry \&Physiology, 90A, 577-82.

39. Stankov M, Obradović V, Obradović J, Vukićević O, 1992, Effect of the mineral adsorbent on state of health and production results of piglets, Veterinarski glasnik, 46, 91-6.

40. Stojić V, Gvozdić D, Šamanc H, Jovanović I, Fratrić Natalija, 2005, Thyroid gland hormones in newborn calves treated with clinoptilolite receiving different amounts of colostrum, Acta Veterinaria, 55, 1, 3-10.

41. Stojić V, Gagrčin M, Kirovski Danijela and Fratrić Natalija, 1998. The effect of clinoptilolitebased mineral adsorber immunoglobulin G absorption in newborn piglets, Acta Veterinaria, 48, 19-26.

42. Stojić V, Šamanc H, Fratrić Natalija, 1995, The effect of a clinoptilolite based mineral adsorber on colostral immunoglobulin $\mathrm{G}$ adsorption in newborn calves, Acta Veterinaria, 45, 2-3, 67-74.

43. Stott GH, Fleenor WA, Kleese WC, 1981, Colostral immunoglobulin concentration in two fractions of first milking postpartum and five aditional milkings, J Dairy Sci, 64, 459-65.

44. Stott GH, Felahh A, 1983, Colostral immunoglobulin absorption linearly related to concentration for calves, J, Dairy Sci, 66, 1319-28.

45. Stott GH, Marx BD, Menefee EB, Nightengale TG, 1979, Colostral immunoglobulin transfer in calves II. The rate absorption, J Dairy Sci, 62, 1766-73.

46. Tomašević-Čanović M, Dumić M, Vukićević O, Mašić Z, Zurovac-Kuzman O, Daković A, 1995, The adsorption of mycotoxins on modified clinoptilolite, Sofia Zeolite Meeting, Intern, Symp, on Natural Zeolite, Sofia, 78.

47. Vukotić M, 1972, Neki vidovi heterogenosti imunoglobulina G govečeta. Doktorska disertacija. Veterinarski fakultet, Beograd.

48. Vukotić M, Movsesian M, 1976, A relationship between the concentrations of immunoglobilin $\mathrm{G}$ in precolostral and postcolostral sera of calves, Acta Veterinaria, 26, 181-6.

49. Weaver DM, Tyler JW, Barrington GM, VanMetre DC, Hostetler DE, 2000, Passive transfer of colostra immunoglobulins in calves, $J$ Vet Intern Med, 14, 569-77. 


\title{
EFEKAT MINERALNOG ADSORBENTA NA NIVO SERUMSKIH IMUNOGLOBULINA G, PROTEINA I GLUKOZE KOD TELADI NA KOLOSTRALNOJ ISHRANI
}

\author{
FRATRIC NATALIJA, STOJIC V, RAJČIĆ S i RADOJIČIĆ BILJANA
}

\begin{abstract}
SADRŽAJ
Cilj ovog rada bio je da se ispita uticaj mineralnog adsorbenta na bazi klinoptilolita na stepen resorpcije IgG i koncentraciju nekih biohemijskih parametara u krvnom serumu teladi u neonatalnom periodu.

Telad su bila podeljena u četiri grupe (po 15 teladi u svakoj grupi). I grupa teladi napajana je sa kolostrumom $2 \mathrm{~h}, 12 \mathrm{~h}, 24 \mathrm{~h}$ i $36 \mathrm{~h}$ posle rođenja, II grupa teladi napajana je sa kolostrumom u koji je dodat mineralni adsorbent u koncentraciji od $5 \%$ u istim vremenskim intervalima, III grupa napajana je sa 1,5 L kolostrumom u koji je dodat mineralni adsorbent u koncentraciji od $5 \%$ ali $2 \mathrm{~h} \mathrm{i} 12 \mathrm{~h}$ posle rođenja napajana su prvim kolostrumom, a 24h i 36h dugim kolostrumom, IV grupa teladi hranjena je na isti način kao i III grupa samo što u kolostrum nije bio dodat mineralni adsorbent.

Koncentracija IgG u krvnom serumu teladi od I do IV grupe, 6 sata iznosila je pojedinačno $15,14 \pm 7,43 ; 22,22 \pm 8,15 ; 23,65 \pm 9,93 ; 20,81 \pm 4,19 \mathrm{~g} / \mathrm{L}$. U krvnom serumu teladi kod svih ispitivanih grupa koncentracija IgG u $16 \mathrm{~h}$ iznosila je pojedinačno $29,10 \pm 15,25 ; 45,46 \pm 13,45 ; 50,72 \pm 21,57 ; 41,60 \pm 15,42$ g/L. Koncentracija IgG 30sata kod ispitivanih grupa teladi (I do IV) bila je pojedinačno $33,29 \pm 14,70 ; 47,05 \pm 12,38 ; 55,00 \pm 19,71 ; 51,59 \pm 13,82 \mathrm{~g} / \mathrm{L}$. Koncentracija IgG u krvnom serumu svih grupa $40 \mathrm{~h}$ iznosila je $29,82 \pm 12,69 ; 44,10 \pm 13,50 ; 51,88 \pm$ 20,$14 ; 47,68 \pm 13,18 \mathrm{~g} / \mathrm{L}$ pojedinačno.

Kod teladi koja su napajana punim kolostrumom bez i sa dodatkom mineralnog adsorbenta (I i ll grupa) utvrđena je statistička značajnost razlike u koncentraciji IgG u svim ispitivanim intervalima. Koncentracija IgG u krvnom serumu teladi koja su napajana kolostrumom sa dodatkom zeolita (II grupa) bila je oko 30\% veća u odnosu na I grupu. Statistički značajna razlika u koncentraciji IgG utvrđena je i poređenjem I grupe sa III i IV u svim ispitivanim intervalima. Koncentracija IgG u krvnom serumu kod III grupe teladi bila je za $40 \%$ veća nego u I.

Rezultati su ukazali da kod teladi koja su napajana kolostrumom visokog kvaliteta, u koji je dodat mineralni adsorbent, dolazi do maksimalne adsorpcije IgG. Određivanje proteinemije kod teladi u neonatalnom periodu je pouzdan pokazatelj uticaja mineralnog adsorbenta na resorpciju kolostralnih IgG. Koncentracija glukoze kod svih oglednih grupa se značajno povećava sa povećanjem broja uzezih kolostruma, bez većeg uticaja mineralnog adsorbenta.
\end{abstract}

